Article

\title{
Entrepreneurial Orientation, Knowledge Utilization and Internationalization of Firms
}

\author{
Krzysztof Wach * ${ }^{\mathbb{D}}$, Agnieszka Głodowska ${ }^{\mathbb{D}}$ and Marek Maciejewski $\mathbb{D}$ \\ Department of International Trade, Cracow University of Economics, Rakowicka 27, 31-510 Kraków, Poland; \\ glodowsa@uek.krakow.pl (A.G.); maciejem@uek.krakow.pl (M.M.) \\ * Correspondence: wachk@uek.krakow.pl; Tel.: +48-12-293-5376
}

Received: 15 November 2018; Accepted: 7 December 2018; Published: 11 December 2018

check for updates

\begin{abstract}
The aim of this article is to verify what the relations are between entrepreneurial orientation and knowledge utilization in the internationalization of Polish firms. The article distinguishes four types of knowledge: market knowledge, network knowledge, sociocultural knowledge, and entrepreneurial knowledge. The research uses quantitative design and is based on a survey conducted in 2015 on a sample of 355 businesses from Poland (the response rate was 10.7\%), following which statistical techniques ( $t$-tests and regression analyses) were applied to verify the hypotheses. An overview of prior studies enabled us to identify the research gap in the literature regarding the combination of three elements that link to form one picture of reality, namely, (i) entrepreneurial orientation and (ii) knowledge utilization in (iii) the internationalization process of firms. The case of Polish firms confirms that entrepreneurial orientation is substantial in the use of knowledge in the internationalization process. Firms characterized by higher entrepreneurial orientation use particular types of knowledge much more intensely at various stages of the internationalization process. Entrepreneurial orientation, and especially risk-taking, has significant positive effects on the scope of internationalization. Greater entrepreneurial orientation increases the number of foreign markets in which a given firm operates. Not only market knowledge in the traditional approach, but especially network and entrepreneurial knowledge have significant positive effects on the intensification of the internationalization scale.
\end{abstract}

Keywords: entrepreneurial orientation; international entrepreneurial orientation; knowledge utilization; internationalization; international business; international entrepreneurship; entrepreneurial internationalization; Poland

\section{Introduction}

The importance of entrepreneurship for economic development in emerging economies was observed in various empirical studies (e.g., [1-4]). An example of such an economy is Poland, where entrepreneurship and self-employment have always been practiced. Even during the centrally planned economy, the situation is Poland was much different from that in other countries of the socialistic block [5]. Nevertheless, its real development took place along with the economic transformation after 1990 [6]. The removal of the legal barriers that had hindered the development of private initiatives in a state-controlled economy enabled people to open their own businesses [7]. New economic conditions provided great opportunity for the development of private firms, especially for small and medium-sized enterprises (SMEs). In the last two decades, constant development of entrepreneurship in Poland has been observed [8]. The promotion of entrepreneurship is included in the most important strategic development documents of Poland [9]. Numerous studies by the Global Entrepreneurship Monitor [10] have found that starting and managing new businesses is more popular in Poland on the average than in other country in the European Union (EU). A similar situation can be observed as 
far as nascent and potential entrepreneurs are concerned. Almost a quarter of Poles are thinking of starting a new business within the period of the forthcoming 3 years [9].

What is more, initially, the openness of the economy in the 1990s, and then the enlargement of the European Union (EU) created new possibilities for entrepreneurs in Poland, who can, in principle, make use of the EU's freedom of enterprise to conduct business in all countries of the EU. Although Polish entrepreneurs are latecomers (due to the relative closeness of the economy in the past) in international business from the global perspective, international entrepreneurship (IE) among Polish entrepreneurs and businesses seems to be flourishing. Entrepreneurial orientation (EO), as a stimulant of entrepreneurial activities in international markets, is of special importance here.

Entrepreneurial orientation in the international context is a research topic that has been systematically developed within studies on international entrepreneurship, which in turn consolidate the concepts of entrepreneurship and international business. In this article, entrepreneurial orientation refers to the process of the internationalization of firms, which is a substantial contribution to the research on internationalization understood as an entrepreneurial process-in other words, entrepreneurial internationalization. The approach of international entrepreneurship or entrepreneurial internationalization, introduced to the literature by Oviatt and McDougall $[11,12]$ as well as by Knight and Cavusgil [13], completely revolutionized the traditional attitude towards the internationalization of firms and opened a new perspective domain of research exploration adapted more to current changes in the international environment and emphasizing the entrepreneurial aspects of this process $[14,15]$. To date, some researchers have investigated how EO impacts firm performance (e.g., [16-18]) or internationalization (e.g., [19-23]), while other researchers have found some empirical evidence that the knowledge management process (knowledge acquisition, sharing, and utilization) impacts the internationalization of a firm [24-31]. The effects of knowledge of internationalization and the effects of entrepreneurial orientation on internationalization have been discussed independently by previous researchers such as Etemad [19], Hsu, Chen and Chen [32], Tolstoy [33], and Yoon, Kim, and Dedahanov [34].

The latest studies indicate the need to combine these issues as essential and unique [35,36]. Cui, Fan, Guo, and Fan [36] provided an integrated explanation of the role of capability development mechanisms underlying the performance effect of EO. Based on a sample of 411 Chinese small firms, they found that EO is a mediating variable for knowledge-based capability and firm performance. In our study, we refer to Polish businesses, including all firms, regardless of their size. In addition, we not only position knowledge between entrepreneurial orientation and internationalization, but we also try to identify the existing relationship between these variables. Based on a sample of 220 banks in Malaysia, Hanif, Malik, and Hamid [35] proved that knowledge acquisition, sharing, and utilization (as three components of the knowledge management process) have a positive effect on firm performance; meanwhile, innovativeness, proactiveness, and risk-taking (as three components of international entrepreneurial orientation) also have a positive effect on firm performance in the banking sector. They investigated these variables separately; in contrast, we would like to make a step forward and put these variables together by investigating the impact of entrepreneurial orientation on the knowledge management process. In this study, we address this knowledge gap by asking the following research questions:

RQ1 - What are the relations between entrepreneurial orientation and the internationalization of firms? RQ2 - What are the relations between entrepreneurial orientation and knowledge utilization in the internationalization of firms?

RQ3-What are the relations between knowledge and the entrepreneurial internationalization of firms? RQ4-How does entrepreneurial orientation utilize different types of knowledge (market knowledge, sociocultural knowledge, entrepreneurial knowledge) in the internationalization of firms?

A new view of the studied problem, representing the added value of this paper, is the inclusion of knowledge and its role in the internationalization process determined by the influence of 
entrepreneurial orientation. This new perspective represents a research gap in the literature and these relations are as yet unexplored. What is more, there is an evident lack of studies on emerging countries, including countries in Central and Eastern Europe. This paper makes three contributions towards progressing and updating the research on entrepreneurial orientation. First, it links three separate variables into one merged topic of research, namely, (i) entrepreneurial orientation; (ii) knowledge utilization; and (iii) the internationalization of firms. Second, it clarifies how entrepreneurial orientation impacts the use of various types of knowledge. Third, it contributes to the existing literature of international entrepreneurship by testing entrepreneurial orientation in a more recent context, and in the emerging economy in Central and Eastern Europe (specifically Poland), a region where almost no research into international entrepreneurial orientation has been conducted before [36,37].

Therefore, the aim of the article is to verify the relations between entrepreneurial orientation and knowledge utilization in the internationalization process of Polish firms. The research method applied in the paper involves the analysis and synthesis of the literature of the subject, statistical methods, as well as a survey conducted on a sample of 355 businesses from Poland.

The article is divided into interrelated sections. The first section gives a general overview of the research problem and indicates the research questions this article addresses. The second section presents the results of prior studies, revealing the research gap addressed by this article. It also includes a conceptual analysis and explains the significance of entrepreneurial orientation in the internationalization process. Then, different typologies of knowledge are presented and their roles in the internationalization of firms is shown. The section ends with an overview of existing studies combining entrepreneurial orientation, knowledge, and internationalization, showing the combination of these three problems to be a current research gap. The third section presents the research methodology used in the article, specifically research methods and variables. The fourth section discusses the research findings in detail. The last section, besides providing a summary of the empirical findings, reveals the research limitations and indicates suggestions for further studies.

\section{Literature Review: Prior Studies, Research Gap and Hypotheses Development}

\subsection{Entrepreneurial Orientation and Internationalization}

In the opinion of Shane and Venkataraman [38], entrepreneurship can be understood as the search for, creation, and use of opportunities. Therefore, it includes the entirety of decisions and actions related to the launch and performance of a new venture under conditions of uncertainty [20]. There is no universal and proven definition of the term entrepreneurship due to the fact that it is an ambiguous and multi-faceted subject [21]. In a broad sense, entrepreneurship is identified as entrepreneurial orientation, which is its foundation. Zahra [39], as well as Dess and Lumpkin [16], emphasize that entrepreneurial orientation refers to the potential entrepreneurial intentions of firms, which is to say their readiness and propensity to undertake entrepreneurial activities. According to Krueger and Carsrud [40], entrepreneurial intentions are a causative factor of entrepreneurial activities. The theoretical foundations for entrepreneurial orientation lie in the core theory of entrepreneurship, especially in the psychometric approach, as entrepreneurial orientation seems to constitute the essence of entrepreneurship [41].

Entrepreneurial orientation and its dimensions can serve to assess the level of firms' entrepreneurship. Typical conceptualizations of entrepreneurial orientation distinguish its three dimensions: (i) proactiveness; (ii) risk-taking; and (iii) innovativeness [17,42]. Lumpkin and Dess [18] proposed the use of two additional dimensions: (iv) competitive aggressiveness and (v) autonomy.

Proactiveness refers to the firm's efforts focused on the use of new opportunities [43], which should be understood as the appropriate recognition of future needs and the launch of products before the competition [18]. Innovativeness consists in creativity and propensity to experiment in the introduction of new products [18]. Risk-taking is related to the readiness to undertake daring activities, such as entering new, unknown markets, and the engagement of considerable resources 
in the implementation of ventures with uncertain outcomes $[18,20,44]$. Competitive aggressiveness refers to relations with market rivals and consists in outrunning them in satisfying customer needs, whereas autonomy consists in the entrepreneur's independence during the whole process of this process implementation [18].

There are two main approaches in the conceptualization of entrepreneurial orientation adopted in research. The first one, put forth by Covin and Slevin [17], is based on the three dimensions of EO, and the second, proposed by Lumpkin and Dess [18], is a multi-dimensional approach, in which individual dimensions can appear in various combinations.

Covin and Miller [45] claimed that the issue of international entrepreneurial orientation (IEO) should be analyzed in relation to entrepreneurial orientation and international entrepreneurship.

Initially, research into entrepreneurship and international business was conducted in separate areas. The analysis of international business was limited to large multinational firms, whereas entrepreneurship researchers focused on the foundation of firms and the management of small and medium-sized enterprises (SMEs) in the domestic context [46]. Only in 1990s were attempts made to combine separate entrepreneurial and internationalization concepts, creating a new field of international entrepreneurship in the literature, within which the internationalization process of firms was included in the main strand of research into entrepreneurship [47]. McDougall and Oviatt, pioneers in this field, acknowledged that "international entrepreneurship is a combination of innovative, proactive, and risk-seeking behavior that crosses national borders and is intended to create value in organizations" [48] (p. 903). Therefore, they emphasized the significance of those characteristics which initially had been commonly used to determine the entrepreneurial orientation of firms on the domestic scale. Knight [49] suggested that the three-dimensional construct of international entrepreneurial orientation is the main factor determining the international performance of a firm. Covin and Miller [45] paid attention to the fact that newer definitions of international entrepreneurship refer less clearly to entrepreneurial orientation. Oviatt and McDougall [12] (p. 540) also observed this in a more recent approach, as they defined international entrepreneurship as "the discovery, enactment, evaluation, and exploitation of opportunities across national borders to create future goods and services". Gabrielsson et al. [47] observed; however, that placing emphasis in the definition on opportunities does not mean that the interest in the aforementioned three dimensions of entrepreneurship should be abandoned. They suggested that by combining innovativeness, proactiveness, and risk-taking, firms should try to use their opportunities by entering the international market.

On the grounds of theory, it is appropriate to associate entrepreneurial orientation and knowledge with the internationalization process, but in the existing studies those issues are only addressed as individual (independent, separate) research problems, not related directly. Entrepreneurial orientation in itself has been one of the most important research topics within research on entrepreneurship since as early as the late 1980s, but its implementation in studies on international business took place much later [50]. The first works combining entrepreneurial orientation with the international dimension of business appeared at the end of the 1990s. In his paper, Knight [51] combined entrepreneurial orientation with the functioning of firms in various international cultures. In other works, individual attributes of entrepreneurial orientation are selectively combined with the internationalization processes [52-56]. Research conducted in the following years led to the widely accepted definition of the term international entrepreneurial orientation based on the three basic components of entrepreneurial orientation: innovativeness, proactiveness, and the capability of risk-taking [48,49]. Knight [49] proved that this three-dimensional concept is the main factor of success, determining the international accomplishments of firms. The positive relation between entrepreneurial orientation and the internationalization process was observed in numerous empirical works $[19,33,52,57,58]$. Very few researchers reported an insignificant relation between entrepreneurial orientation and internationalization [59] or indicated a negative relation between the two factors [60].

Florida [52] was one of the first to prove that entrepreneurial orientation incites firms to undertake new ventures by penetrating international markets to sell their innovative products. Etemad [19] 
revealed that, among the key factors influencing the effectiveness of the international activities of firms, entrepreneurial orientation is the most significant. The success of internationalization, according to this author, depends on the three components of entrepreneurial orientation. Emöke-Szidónia [61] emphasized that small and medium-sized enterprises with high entrepreneurial orientation are leading entities of transition countries in Europe. The varied influence of entrepreneurial orientation on the widely approached internationalization process was indicated by Zahra and Covin [62], as well as by Rauch et al. [22], who observed that entrepreneurial orientation is more significant in the long-term approach although its influence is not identified in the short term. However, Rauch et al. [22] observed a stronger impact of entrepreneurial orientation on firms' financial effectiveness than on their marketing effectiveness. A great number of papers have associated entrepreneurial orientation with other factors that determine the internationalization process. Zuccehella [23] studied determinants of internationalization, such as technological, marketing, and network capabilities, and found that they are of crucial significance for internationalization, as well as that their interaction with entrepreneurial orientation plays a substantial role in the effectiveness of internationalization. The great importance of entrepreneurial orientation, and especially of proactiveness in the internationalization process, is stressed by authors who study born global firms and new international ventures, indicating that firms of this type are in their nature entrepreneurially oriented, operating proactively all over the world [63-66]. On the other hand, risk-taking is exposed in many research elaborations as the most important determinant of entrepreneurial orientation, as it plays an important role in a firm's performance in overseas markets $[34,57,67]$

This study developed the following research hypotheses based on theory and previous empirical findings. Furthermore, this paper explores the empirical relationships between the research hypotheses.

Hypotheses 1 (H1). Entrepreneurial orientation has significant positive effects on the scope of internationalization. The higher the entrepreneurial orientation, the greater the number of foreign markets in which a firm can operate.

Hypotheses 1 (H1a, b, c). Such dimensions of entrepreneurial orientation as (a) innovativeness; (b) proactiveness; and (c) risk-taking have significant positive effects on the scope of internationalization.

\subsection{Knowledge and Internationalization}

Knowledge is also of fundamental significance in coping with the uncertainty by which internationalization is characterized. Therefore, knowledge and learning are conducive to a firm's growth, giving motivation towards internationalization and the search for opportunities on new markets. They strengthen the competitive position of a firm via the optimum use of the resources at its disposal. This is particularly important for SMEs, which in comparison to large enterprises have a smaller potential of tangible assets. Therefore, knowledge is of key significance for their survival and growth [24].

Research on the microeconomic level of the internationalization of SMEs is relatively new in comparison with analyses of international trade. This research only dates back to the mid-20th century. Knowledge is assumed to be the key variable explaining the internationalization process of SMEs. Initially, this process took place particularly in stages, the models of which date back to the 1970s. Knowledge as a variable of internationalization process modeling became more important in the last two decades of the 20th century. The heyday of knowledge-based as well as learning-based internationalization models occurred at the turn of the first and the second decade of the 21st century [68]. It should also be stressed that individual authors, acknowledging the significance of knowledge in the internationalization process, put emphasis on the types, roles, and sources of knowledge differently.

The most famous stages model is regarded to be the Uppsala model by Johanson and Vahlne [69]. This model assumed a stepwise internationalization process, starting from the lack of regular export activity, through to export with the use of intermediaries, trade subsidiaries, and reaching the highest 
involvement of manufacturing subsidiaries, characterized by the highest level of engagement on foreign markets. In the stages approach, the internationalization of firms is perceived as an effect of the learning process, which means that growing knowledge triggers a higher engagement of resources on a specific market due to the reduction of risk and uncertainty related to the engagement on this market [70]. In this approach, knowledge refers mainly to the market knowledge, with the firm's own experience being its source, and its role being the regulation of the volume of the resources engaged on foreign markets [71].

A different approach was presented in the 1990s by Oviatt and McDougall [10], in response to the growing significance of international ventures already undertaken in the first phase of the firm's development. They emphasized the role of the technological intensity of knowledge which has its sources in the previous experience of the entrepreneur. This knowledge enables the firm to offer their product on a global scale.

With respect to the sources of acquiring knowledge that is useful in the internationalization process, attention is paid to the modes of its acquisition-direct or indirect-which influence the speed of this process [25]. Direct learning consists in a change in the firm's knowledge base as an effect of the activities undertaken by that firm, the result of which is a change in the future behaviors as a direct consequence of the experience gained [26]. The focus exclusively on this mode of learning was one of the bases of the criticism of the Uppsala model [72]. Indirect learning refers to the process in which the firm learns based on the effects of activities of other entities, changing its behavior as a result of the experiences of others. Here, the assumption is made that indirect learning runs more quickly than direct learning. Its effect is that newly established business entities operating within international parent companies can derive from the experiences of affiliated entities, which places them in a privileged position in the process of the internationalization of their activity [25]. We conclude that a similar effect can be achieved by using network relationships, which assume internationalization in the process of intraorganizational and interpersonal relationships, requiring cooperation and mutual learning. Sharing knowledge and experience enables firms to overcome barriers related to apprehensions towards foreign markets.

The classification of the types of knowledge used in the internationalization process was made by Eriksson et al. [27] in late 1990s, who distinguished business knowledge and knowledge about internationalization. Business knowledge includes issues related to the specificity of the industry; that is, technical characteristics of the product, relationships with customers, competitors and partners, as well as issues connected to the institutional environment, including the rights and standards of the foreign market. Knowledge about the internationalization process concerns the process of the firm's management outside the home country. It is analyzed in the dimension of diversity, which refers to the number and variety of markets in which the firm is present and the depth of the experience identified with the period of activeness in foreign markets. Akerman [28] paid attention to the fact that the increment of knowledge entering another market that similar to the existing knowledge becomes less and less useful. This also applies to longer experiences and obtaining information on the same markets. This means that, with time, the increment of knowledge of internationalization will lose its dynamics.

Mejri and Umemoto [24] paid a special attention to SMEs and focused on the internationalization process itself in their knowledge-based model, which is rooted in international entrepreneurship distinguished by four types of knowledge: market, network, cultural, and last but not least entrepreneurial knowledge. Market knowledge refers to the information on foreign markets, including their size, competitors, and regulations. The acquisition of this type of knowledge in the pre-internationalization period is of key importance for undertaking internationalization and in the first phase of its process. Using this type of knowledge in the novice internationalization phase arises from the need to acquire any available information on the target market due to the high level of risk related to entering the given market. With the increasing engagement in the internationalization process, the intensity of the use of knowledge about the market decreases in favor of the growth of significance of empirical knowledge. In the category of empirical or experimental knowledge, 
Mejri and Umemoto [24] included network, sociocultural, and entrepreneurial knowledge. Network knowledge is acquired within the functioning of firms in formal and informal social and business networks in the pre-internationalization period and in its first phase. Knowledge acquired as a result of mutual learning and the exchange of experiences enables firms to reduce apprehensions towards foreign markets, which facilitates and accelerates the internationalization of firms, particularly SMEs. It is used to a various extent on individual stages of the internationalization process. Cultural (sociocultural) knowledge refers to the familiarity with the values, attitudes, and mindsets of foreign markets. The acquisition of this type of knowledge begins with the start of the internationalization process. The intensity of the use of sociocultural knowledge grows with the level of its absorption by the firm. Entrepreneurial knowledge refers to the recognition of market opportunities and their use. Knowledge of this type is acquired from the time of a firm's establishment, thus in the period preceding internationalization, and its deepening takes place after foreign market entry. According to Mejri and Umemoto [24], the use of entrepreneurial knowledge of the international market grows with the experience of a firm. The utility of combining entrepreneurial knowledge with internationalization has been empirically supported in many empirical studies [73-78]. What is more, a research gap was identified in the understanding of how entrepreneurial knowledge stimulates motivation, desires, and intentions in foreign markets. Nevertheless, we strongly believe that entrepreneurial knowledge is the essence of entrepreneurial internationalization, and that entrepreneurial knowledge should be considered a key element of various models developed in international entrepreneurship. Therefore, we assume the following research hypothesis:

Hypotheses 2 (H2). Entrepreneurial knowledge plays a significant positive role for entrepreneurial orientation in the experienced internationalization phase.

Knowledge and its significance in the internationalization process is an area much more recognized in the related literature. Empirical research into this problem was conducted in the first place within classical and alternative concepts concerning international trade. Therefore, it was an attempt to empirically verify the influence of knowledge of export or other forms of international activity within selected concepts of international trade [29-31].

Knowledge as a fundamental internationalization factor has been verified empirically also on the grounds on many other theoretical concepts: the Uppsala model [69], the eclectic model [24,71,79], international entrepreneurship theories [48], as well as knowledge-based models [80]. A substantial portion of works focused on knowledge in the stages model by Johanson and Vahlne [69], as well as its polemical concepts, as proposed by McDougall and Oviatt [48]. Prashantham [71] rightly observed that despite the apparent tension between these two approaches, in both we can see a specific albeit varied role of knowledge, including its types and sources. In the approach of Johanson and Vahlne [69], the knowledge necessary to the internationalization process is market knowledge, which contributes to the optimization of the firm's resources engaged in foreign markets. Thus, the lack of market knowledge becomes a substantial obstacle in the internationalization process of firms. Its main source is the firm itself, through experiences collected from foreign markets and through network relationships [32,72,81-85]. McDougall and Oviatt [48] believed that in addition to market knowledge, specialist knowledge related, for example, to technological progress, which enables early internationalization, is particularly important. Examples of this, according to the authors, are programming and biotechnological firms. It is worth noting that not only the type of knowledge but also its intensity is significant here $[71,86,87]$.

The problem of knowledge and internationalization as a common research problem is difficult to systematize. Both knowledge and internationalization are multidimensional issues, thus in scientific research the problem is shown differently. There are numerous papers presenting various classifications of knowledge, whose role in the internationalization process is then verified [24,88,89]. An excellent example of this is the taxonomy by Mejri and Umemoto [24], used in the empirical part of this paper. Recently, the issues of knowledge in the internationalization process have been combined with the 
network relationships of internationalized firms. This takes place as a consequence of the identification of early internationalization, where limited experience and the knowledge derived from it are replaced by acquired knowledge and relationships arising from international networks. Creating networks enables to acquire knowledge about the international market accelerates foreign market entry and aids in the achievement of a competitive advantage [90-95].

Based on the prior empirical studies and the abovementioned theoretical conceptualizations, we assume the following research hypothesis:

Hypotheses 3 (H3). Network and entrepreneurial knowledge have significant positive effects on the intensification of internationalization.

\subsection{Entrepreneurial Orientation, Knowledge, and Internationalization: Merging the Problem}

Recently, Åkerman [28] observed that internationalization, entrepreneurship, and knowledge are closely related. Fletcher [96] postulated that all activities undertaken in the international arena should be regarded as entrepreneurial, since they are related to risk-taking and conditions of uncertainty. Therefore, internationalization is a form of innovation whose significant source is knowledge [71].

Entrepreneurial orientation, knowledge, and their significance in the internationalization process do not have common synthetic empirical rounds in the existing scientific research. There is almost no research in the literature linking these three variables. As a certain attempt to integrate these research problems, we here give an overview of works which combine entrepreneurial orientation with knowledge and the performance of firms. However, there is no direct internationalization aspect in prior studies. Examples of such papers are publications which fragmentarily or selectively treat internationalization in the context of entrepreneurial orientation and knowledge. Wiklund and Shepherd [97], studying small and medium-sized enterprises from Sweden, verified the hypothesis concerning relationships between entrepreneurial orientation, knowledge, and the functioning of the firm (leaving behind the internationalization processes in their research). Ultimately, the authors proved that entrepreneurial orientation has a positive influence on the firm's knowledge-based resources and thus this relationship determines the firm's effectiveness. Li et al. [98] also proved a positive relationship between entrepreneurial orientation and the knowledge creation process, as well as between the knowledge creation process and the effective performance of the firm. The authors proved that the knowledge creation process plays an indirect role in the influence of entrepreneurial orientation on firms. Entrepreneurial orientation is the basis of the indicated relation, and knowledge converts entrepreneurial orientation components into the firm's useful assets. Omar et al. [99] proved the positive impact of entrepreneurial orientation and knowledge of the firm's functioning, but found that entrepreneurial orientation does not play an important role in the knowledge creation process.

For the needs of this article, the knowledge-based internationalization model by Mejri and Umemoto [24] was used, which distinguishes two main types of knowledge: (i) market knowledge coming from written documents, reports, and explicit materials; and (ii) experiential knowledge arising from practice or acquired exclusively via personal experience. What is more, experiential knowledge consists of (iii) network knowledge; (iv) cultural knowledge; and (v) entrepreneurial knowledge. The types of knowledge thus defined were juxtaposed by the authors with the internationalization process in which they distinguished three phases according to the firm's experience level: the pre-internationalization phase, the novice internationalization phase, and the experienced internationalization phase. Different intensities of acquisition and the use of specific types of knowledge apply to each phase, as presented in Figure 1. 


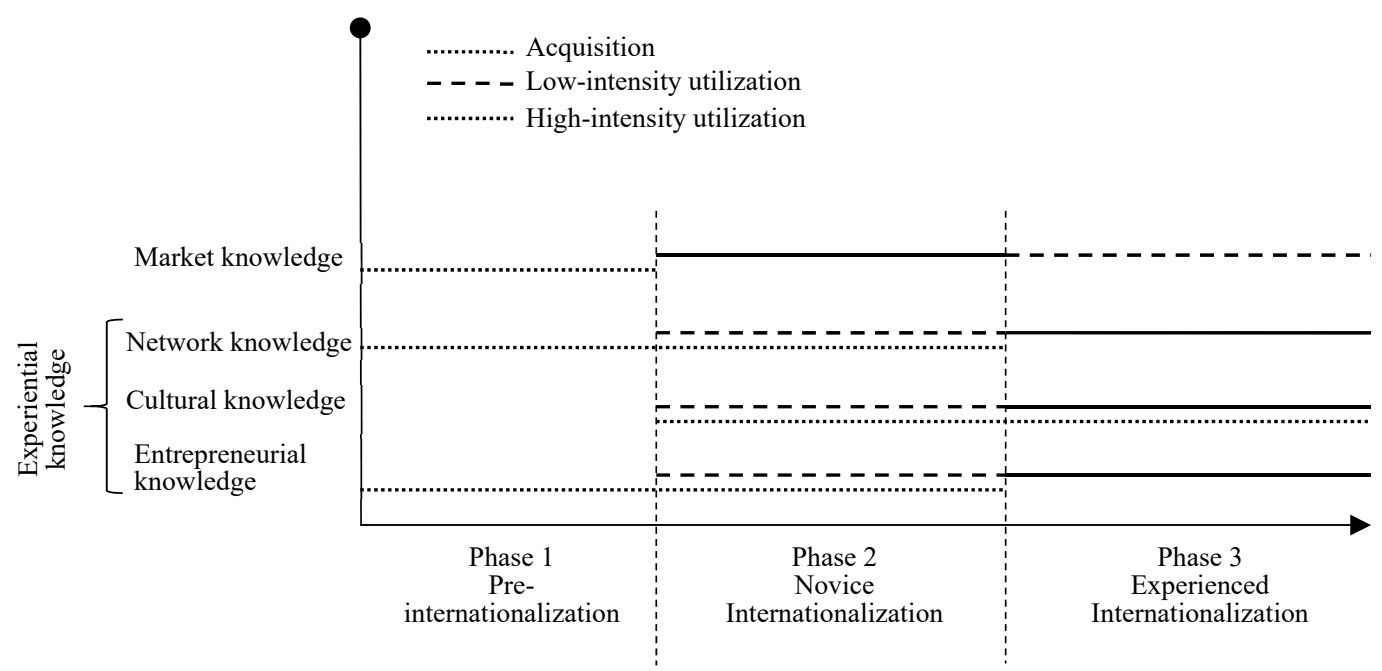

Figure 1. The role of market and experiential knowledge in the internationalization process, according to the concept of Mejri and Umemoto [24] (p. 162).

As already mentioned, Mejri and Umemoto's model [24] assumes a high use of market knowledge in the first period of internationalization and its low use in the case of mature internationalization. On the contrary, experiential knowledge (network, sociocultural, and entrepreneurial knowledge) is subject to high use in the mature phase of internationalization, and low use in the pioneer phase. It is worth supplementing this model with entrepreneurial orientation, since it may be expected that firms with higher entrepreneurial orientation use specific types of knowledge in the internationalization process more intensely than firms characterized by lower entrepreneurial orientation. This concept is the authors' development of the model, combining the output of models based on the knowledge and learning process with the international entrepreneurship school of thought.

To sum up, the conducted overview of research confirms the validity of combining the influence of entrepreneurial orientation on different types of knowledge in the internationalization process. What is more, a substantial shortage of empirical studies in this area is indicated. Gupta and Moesel [100] answered the research question of what the impact of entrepreneurial orientation is on a firm's knowledge management activities in its supply chain. The research of Cui et al. [36] examined the mechanisms through which entrepreneurial orientation affects a firm's performance in China as an emerging market. Therefore, there are very few examples of empirical investigation in the literature linking EO and knowledge management, but to the best of our knowledge, there is no research linking three variables in one investigation (EO, knowledge utilization, and the internationalization of the firm).

The findings of previous investigations and the above discussed theoretical concepts reveal the abovementioned the research gap (the relations between entrepreneurial orientation, knowledge, and the internationalization of the firm) and enabled us to assume the following research hypothesis to be verified empirically:

Hypotheses 4 (H4). Firms with higher entrepreneurial orientation use both market knowledge and experiential knowledge more intensely (i.e., network knowledge, sociocultural knowledge, entrepreneurial knowledge), both in the novice and experienced internationalization phases.

\section{Materials and Methods}

\subsection{Building the Research Model}

Our research applied the quantitative approach, based on a questionnaire survey, which allowed us to assess the internationalization of firms and their knowledge resources. Based on deductive reasoning, we attempted to link data characterizing the surveyed firms and to verify the assumed hypotheses. 
Transposing the above discussed research findings on the role of entrepreneurial orientation and performance with the mediating variable of knowledge onto the grounds of international business, we drew the conclusion that the level of entrepreneurial orientation determines the use of knowledge as well as its types in the internationalization process, as presented in Figure 2. The proposed model takes into account entrepreneurial orientation and knowledge as the two driving forces of the internationalization of the firm. Figure 2 shows direct and indirect relationships between stipulated variables in the proposed research model. Entrepreneurial orientation and its components as well as knowledge have an impact on the scope and scale of internationalization. The identified types of knowledge have different meanings for particular stages of this process. It seems highly desirable to combine entrepreneurial orientation with knowledge. In our opinion, a higher level of entrepreneurial orientation determines a greater use of knowledge in the internationalization process.

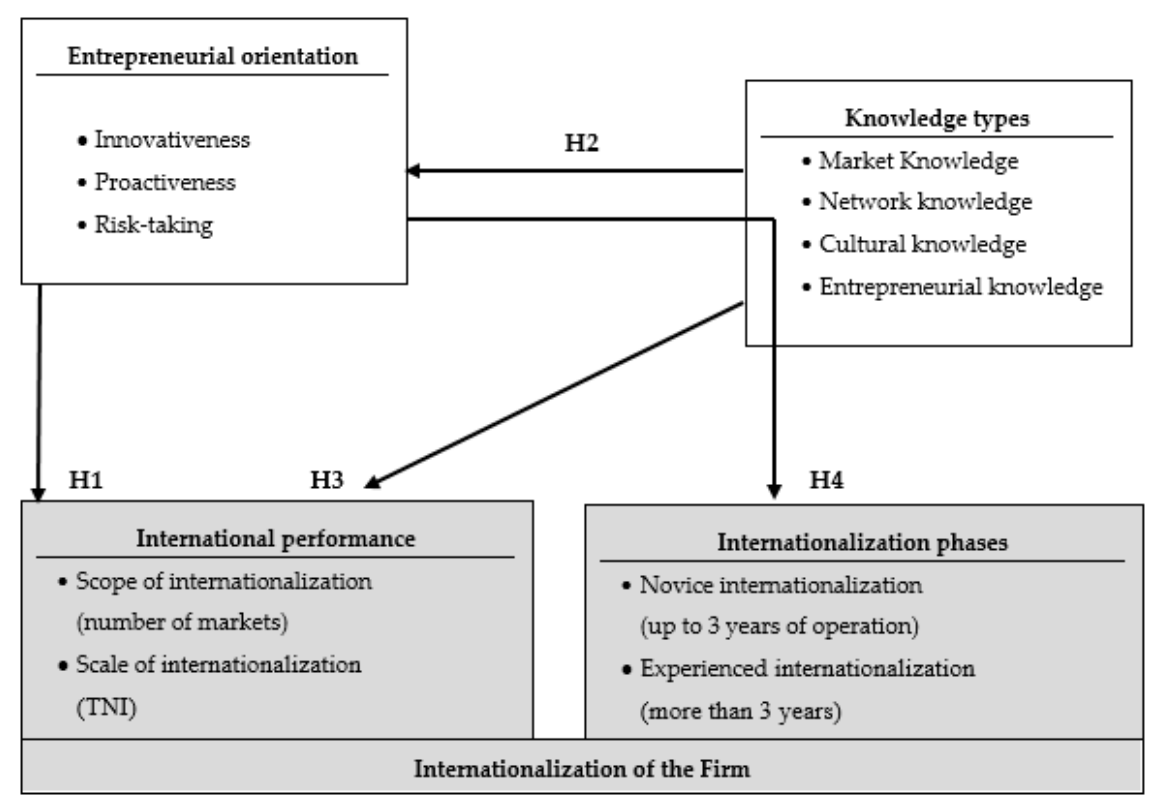

Figure 2. The research model: the impact of entrepreneurial orientation on knowledge in the internationalization process of the firm.

\subsection{The Variables and Their Reliability}

For the needs of statistical calculations and with the use of the survey questionnaire, the following variables were used. First, we employed entrepreneurial orientation and its three dimensions developed by Covin and Slevin [17] as variables. Four of our own variables describing knowledge types (based on the concept of Mejri and Umemoto [24]) as well as two well-known variables describing the performance of internationalization were also used-namely, internationalization scope and transnationality index (Table 1).

Knowledge utilization was measured by four items in two different phases in the survey questionnaire (Table A1). For both, EO measurement as well as knowledge measurement were chosen to represent the operationalization method (a managerial perception), as this method ensures acceptable correctness and reliability. Moreover, it surpasses other methods in terms of practicality of application (as it can be used when there is no secondary data). Lyon, Lumpkin, and Dess [101] cited the argumentation in favor of its use, despite its imperfections. The managerial perception is often used in analogous studies (e.g., [35,36,44]). To our knowledge, the managerial perception is also applied in all studies related to entrepreneurial orientation (e.g., [17,34,35]).

To verify the reliability of items used in the survey questionnaire, we calculated Cronbach's alpha. The overall $\alpha$ statistics for the nine Covin/Slevin [17] items on entrepreneurial orientation was 0.72 and the statistics after deletion of particular items ranged from 0.67 to 0.71 , so there was no need to 
cancel any of the used items. We also used the reliability/item test for eight items on knowledge types (four in novice and four in experienced internationalization). The value of $\alpha$ statistics was 0.82 (even better than that for the Covin/Slevin items [17]) and in the case of individual items it ranged from 0.79 to 0.82 . From the theoretical and methodological point of view, the closer the results are to 1 , the higher the reliability of the scale. Psychometric tests assume that results above 0.7 (even above 0.6 ) indicate satisfactory reliability of the scale. The reliability analysis in our case proved that the used items are reliable and can be employed for further statistical calculations.

Table 1. Dependent and independent variables used in the study.

\begin{tabular}{|c|c|c|c|}
\hline \multicolumn{2}{|c|}{ Variable } & \multirow{2}{*}{ Measures } & \multirow{2}{*}{ Source } \\
\hline Acronym & Full Name & & \\
\hline \multicolumn{4}{|c|}{ Variables describing entrepreneurial orientation } \\
\hline $\begin{array}{l}\text { IEO } \\
\text { IEO_INNO } \\
\text { IEO_PRO } \\
\text { IEO_RISK }\end{array}$ & $\begin{array}{l}\text { Entrepreneurial } \\
\text { orientation } \\
\text { Innovativeness } \\
\text { Proactiveness } \\
\text { Risk-taking }\end{array}$ & Seven-point Likert scale & $\begin{array}{l}\text { Use of measures developed by Covin and } \\
\text { Slevin [17] }\end{array}$ \\
\hline \multicolumn{4}{|c|}{ Variables describing knowledge utilization } \\
\hline $\begin{array}{l}\text { MARK_KNOW } \\
\text { SOCIO_KNOW } \\
\text { NET_KNOW } \\
\text { ENTRE_KNOW }\end{array}$ & $\begin{array}{l}\text { Market knowledge } \\
\text { Sociocultural knowledge } \\
\text { Network knowledge } \\
\text { Entrepreneurial } \\
\text { knowledge }\end{array}$ & Seven-point Likert scale & $\begin{array}{l}\text { Own measures (see Table A1) developed } \\
\text { on the basis of Mejri and Umemoto [24] }\end{array}$ \\
\hline \multicolumn{4}{|c|}{ Variables describing internationalization } \\
\hline INT_SCOPE & $\begin{array}{l}\text { Internationalization } \\
\text { scope }\end{array}$ & $\begin{array}{l}\text { The numbers markets in } \\
\text { which the firm operates }\end{array}$ & $\begin{array}{l}\text { Well-known and well established in the } \\
\text { IB (international business) literature }\end{array}$ \\
\hline TNI & Transnationality index & $\begin{array}{l}\text { Scale from } 1 \text { to } 100 \text { (for } \\
\text { measuring the scale of } \\
\text { internationalization) }\end{array}$ & $\begin{array}{l}\text { Developed by UNCTAD [102] and well } \\
\text { established in the IB literature }\end{array}$ \\
\hline INT_PHASE & $\begin{array}{l}\text { Phase of } \\
\text { internationalization }\end{array}$ & $\begin{array}{l}\text { Dummy } 0 / 1 \text { (novice and } \\
\text { experienced } \\
\text { internationalization) }\end{array}$ & $\begin{array}{l}\text { Retrieved from IE (international } \\
\text { entrepreneurship) literature (e.g., } \\
[13,25,65]) \text {-novice internationalization } \\
\text { up to } 3 \text { years and experienced } \\
\text { internationalization more than } 3 \text { years }\end{array}$ \\
\hline
\end{tabular}

\subsection{The Survey, the Questionnaire, and the Sampling}

Due to the lack of solid and reliable secondary data and the specifics of needed data, we decided to prepare and conduct the survey among Polish businesses of various sizes (micro, small, medium-sized, and large firms). Stratified random sampling was applied in accordance with the following criteria:

(1) The sample includes only internationalized firms (at least experts);

(2) The sample includes firms of different sizes but which reflect research needs-namely, (a) with a small participation of micro-enterprises as the least internationalized, although they are the most numerous group in the studied population; (b) a relatively small participation of large enterprises which, although they are the smallest group in the population, are the most typical research objects in the subject of internationalization (however, it was assumed that each of those groups should be about $10-15 \%$ of the research sample); (c) a relatively large participation of both small and medium-sized enterprises, which, according to the assumptions, should constitute $25-45 \%$ of the sample.

The survey was conducted by means of the Computer-Assisted Telephone Interview (CATI) technique. The survey questionnaire was divided into four thematic parts-namely, (i) the firm's characteristics; (ii) modes and scope of internationalization; (iii) internationalization patterns and strategies; (iv) resources and competences; (v) domestic and foreign environment; (vi) entrepreneurial orientation, and (vi) characteristics of the entrepreneur. 
The research sample was selected based on firms registered in Poland in the REGON (National Business Register), out of which 7100 firms were randomly selected to receive the survey. Out of those firms, only 355 gave their consent to take part in the survey.

Out of the 7100 randomized firms from the REGON, the research sample was theoretically $5 \%$. However, in reality, the randomized part of the population included 3313 firms, and the final research sample was de facto $10.7 \%$ (response rate). A total of 355 questionnaires were collected (Table 2). The reasons for not considering the other firms in the study were as follows:

- $\quad 28.1 \%$ (1991) were not internationalized firms - that is, they did not meet the first criterion;

- $\quad 25.3 \%$ (1796) had a wrong phone number in the REGON, or nobody answered the phone, thus, they could not take part in the research;

- $\quad 22.9 \%$ (1627) refused to participate in the survey;

- $\quad 18.7 \%$ (1331) came across difficulties or caused difficulties for various reasons, which made obtaining reliable responses impossible.

Table 2. Characteristics of the research sample.

\begin{tabular}{lclc}
\hline \multicolumn{2}{c}{ Size of the Firm (in \%) } & \multicolumn{2}{c}{ Sector of the Economy (in \%) } \\
\hline Micro & 14.1 & Agriculture & 1.7 \\
Small & 43.1 & Manufacturing & 56.4 \\
Medium-sized & 29.8 & Construction & 1.9 \\
Large & 13.0 & Trade & 22.4 \\
& & Services & 17.6 \\
\hline \multicolumn{2}{l}{ Foreign } & Ownership (in \%) & Age of Firms (in Years) \\
\hline Average & $\mathbf{2 8}$ & Average & $\mathbf{2 4}$ \\
Min & 0 & Min & 1 \\
Q1 & 0 & Q1 & 14 \\
Median & 0 & Median & 20 \\
Q3 & 68.5 & Q3 & 25 \\
Max & 100 & Max & 183 \\
\hline
\end{tabular}

The results of the telephone interviews were subject to adequate statistical calculations with the use of specialist computer software Statistica PL v. 13.1 and Gretl. The following statistical tools were used to draw conclusions from the gathered empirical material: descriptive statistics, Cronbach's alpha to check the reliability of items in the questionnaire, $t$-test to verify the hypotheses, multivariate regression analysis to show the impact and to verify the hypotheses.

\section{Results and Discussion}

\subsection{Empirical Findings}

As mentioned above, all questions were evaluated by the managers who were the responders for the survey. That is why the managerial perception was applied and all evaluations took place at one time (some questions required both current and retrospective opinions). The use of knowledge was measured in the quasi-dynamic period with the use of the retrospective managerial perception. The period of 3 years was used to define internationalized firms from inception, as the literature of the subject defines a firm if it is considered to be internationalized within the first 3 years from its founding (e.g., [92]). Investigated firms were asked to evaluate four categories of knowledge currently and for first 3 years of operating on foreign markets (see Table 2). Although this is not a pure dynamic approach, from a pragmatic point of view it was impossible to measure it in other way, which is why a quasi-dynamic period was applied.

As for the period of time which passed from the investigated firm's establishment to its internationalization, it fluctuated from 0 to 61 years. According to the median interpretation, in half of 
the cases it was a year and less, and in half it was a year and more (Figure 3). Seventy-five percent of the studied firms internationalized in the eighth year of activity at the latest, and only $10 \%$ in the whole sample undertook foreign expansion after 16 years from inception. The majority of firms-that is, in as many as $61.5 \%$ of cases-reported fast internationalization (namely, 3 years from inception).

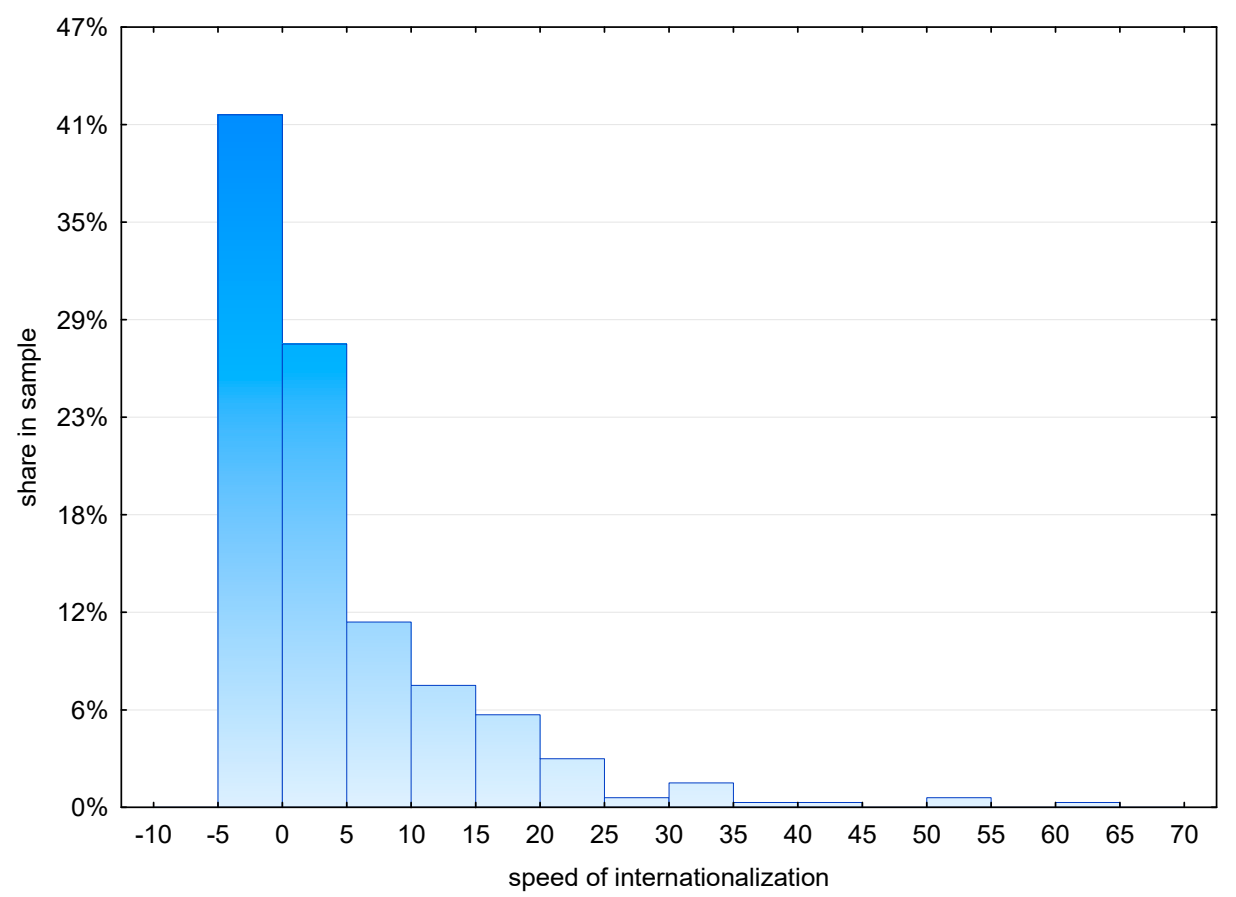

Figure 3. Distribution of the internationalization speed of investigated firms (in years).

We estimated multivariate regression model with ordinary least squares method (OLS) to empirically test our hypotheses. We checked the correctness of the regression models based on the residual analysis (heteroscedasticity versus homoscedasticity). The normality of the residual distribution was evaluated by analyzing the normality diagram of the residuals. The analysis of the graphs allowed us to conclude that the distribution of residues does not deviate from the normal distribution. The assumption of the same variation of the residuals was checked using the White test in the Gretl program. $p$-value statistics at the level from 0.47 to 0.9 did not allow us to reject the null hypothesis that heteroscedasticity is not present, which indicates homoscedasticity of the residual component variation. This means that the homogeneity of variation occurs; i.e., all outliers are correctly described by the models. Using the overall $F$ test to verify significance of the whole model, we find that our model is statistically significant [103].

\subsubsection{Positive Effect of EO on the Scope of Internationalization}

The results included in Table 3 positively verified the $\mathrm{H} 1$ hypothesis about the impact of entrepreneurial orientation on the level of internationalization of a firm, especially in relation to innovativeness and risk-taking. We found that risk-taking and innovativeness have positive impacts on the level of internationalization.

\subsubsection{Positive Effect of Knowledge Utilization on Internationalization Scale}

The results contained in Table 4 confirm the $\mathrm{H} 3$ hypothesis that different types of knowledge are in favor of the internationalization of firms. This applies not only to market knowledge, but also to network and entrepreneurial knowledge, for which a higher level of statistical significance was found. The increase of entrepreneurial, market and network knowledge are positively associated with the scale of internationalization. 
Table 3. Regression summary for the dependent variable of internationalization scope (INT_SCOPE) and the independent variable of entrepreneurial orientation as well as its dimensions.

\begin{tabular}{ccc}
\hline Variable & Internationalization Scope (INT_SCOPE) \\
\hline Model 1 & Model 2 \\
\hline Intercept & 3.992 & 3.993 \\
& $(0.088)$ & $(0.088)$ \\
\hline \multirow{2}{*}{ Entrepreneurial orientation } & $1.728^{* * *}$ & \\
\hline Innovativeness & $(0.002)$ & $1.075^{* *}$ \\
\hline Proactiveness & & $0.016)$ \\
\hline Risk-taking & & 0.232 \\
& & $0.631)$ \\
\hline$F$-value & & $0.112{ }^{* *}$ \\
$p$-value & 9.509 & $(0.042)$ \\
$R$-squared & 0.002 & 3.346 \\
$N$ & 0.027 & 0.010 \\
& 350 & 0.031 \\
& Note. ${ }^{* * *} p<0.01 ; * *<0.05$. & 350 \\
\hline
\end{tabular}

Table 4. Regression summary for the dependent variable of transnationality index (TNI) and the independent variable of knowledge type.

\begin{tabular}{cc}
\hline Variable & Transnationality Index (TNI) \\
\hline Intercept & 2.500 \\
Market knowledge & $(0.620)$ \\
& $1.592^{*}$ \\
Network knowledge & $(0.082)$ \\
& $0.056^{* *}$ \\
Cultural knowledge & $(0.011)$ \\
& -1.047 \\
Entrepreneurial knowledge & $(0.187)$ \\
& $0.065^{* *}$ \\
$F$-value & $(0.020)$ \\
$p$-value & 6.143 \\
$R$-squared & 0.000 \\
$N$ & 0.068 \\
& 350 \\
\hline \multicolumn{2}{c}{ Note. ${ }^{* *} p<0.05 ;{ }^{*} p<0.1}$.
\end{tabular}

\subsubsection{Impact of EO on the Use of Knowledge in Various Phases of Internationalization}

It was found that only 65 out of the 355 firms in the study sample were characterized by a high IEO indicator (the average from "risk-taking", "proactiveness", and "innovativeness" was equal to at least 5 , using a seven-point Likert scale). The firms were characterized by a slightly, although statistically insignificant, higher market knowledge. On the other hand; however, they were characterized by significantly higher network knowledge. Yet, no differences between firms in terms of sociocultural knowledge between firms considering the IEO indicator were found. Taking into account the classification, it was observed that firms with higher IEO were characterized by a statistically significant higher level of entrepreneurial knowledge. In general, firms with a higher IEO indicator were characterized by a higher level of knowledge of three discussed levels-namely, market (which was statistically insignificant), network, and entrepreneurial knowledge. Such a relationship was not discovered for sociocultural knowledge. Thus, the experienced internationalization firms with a higher IEO use network and entrepreneurial knowledge more intensively. 
We also checked whether an analogous situation had taken place 3 years before the study was conducted by using the retrospective managerial perception. Based on the Student's test ( $t$ statistics) for investigated firms, it was found that higher IEO indicator values were previously accompanied by statistically significant higher values of market knowledge. An analogous situation was found for the indicators of network knowledge, sociocultural knowledge, and entrepreneurial knowledge.

The obtained results (Table 5) univocally prove that higher entrepreneurial orientation intensifies the use of entrepreneurial knowledge and network knowledge at the experienced internationalization stage and at the novice internationalization stage, which is the essence of international entrepreneurship. The calculations made do not enable us to make general conclusions concerning experiential knowledge en bloc (as there is no confirmation for sociocultural knowledge).

Table 5. Results of $t$-test linking four types of knowledge with entrepreneurial orientation (EO) during the novice and experienced internationalization phases.

\begin{tabular}{ccc}
\hline Variable & $\begin{array}{c}\text { Novice Internationalization (First 3 Years } \\
\text { of Operating on Foreign Markets) }\end{array}$ & $\begin{array}{c}\text { Experienced Internationalization (After at Least } \\
\text { 3 Years of Operations on Foreign Markets) }\end{array}$ \\
\hline \multirow{2}{*}{ Market knowledge } & $1.385^{* *}$ & $-0.782^{*}$ \\
& $(0.043)$ & $(0.217)$ \\
\hline \multirow{2}{*}{ Network knowledge } & $-2.352^{*}$ & $-1.806^{* *}$ \\
& $(0.096)$ & $(0.035)$ \\
\hline \multirow{2}{*}{ Cultural knowledge } & $-2.376^{*}$ & 1.911 \\
& $(0.081)$ & $(0.689)$ \\
\hline \multirow{2}{*}{ Entrepreneurial knowledge } & $-4.708^{* * *}$ & $-1.736^{* *}$ \\
\hline$N$ & $(0.000)$ & $(0.041)$ \\
\hline & 353 & 353 \\
\hline
\end{tabular}

In the novice internationalization phase, in addition to market knowledge (which is compliant with theoretical bases), firms with higher entrepreneurial orientation were found to use sociocultural knowledge (being one of the three components of experimental knowledge) more intensely, which may positively influence the course of the firm internationalization process. Thus, entrepreneurial orientation may stimulate internationalization much earlier than has been assumed in earlier theoretical concepts which do not consider entrepreneurial orientation. Therefore, the statistical calculations can only partially support the $\mathrm{H} 4$ hypothesis stating that firms with higher entrepreneurial orientation use both market knowledge and experiential knowledge more intensely (i.e., network knowledge, sociocultural knowledge, entrepreneurial knowledge), both in the novice and experienced internationalization phases.

\subsubsection{Stimulating Effect of Knowledge Utilization on EO in an International Context}

The results summarized in Tables 5 and 6 indicate the importance of entrepreneurial knowledge for the entrepreneurial orientation of firms on international markets, which itself confirms the $\mathrm{H} 2$ hypothesis. The recognition of market opportunities and knowledge about their uses turned out to be statistically significant both at the novice and experienced internationalization phases (Table 5). Moreover, research has shown that in the experienced phase of internationalization, only entrepreneurial knowledge has a statistically significant impact on the entrepreneurial orientation of companies (Table 6). 
Table 6. Regression summary for the dependent variable of EO in the experienced internationalization phase.

\begin{tabular}{cc}
\hline Variable & Entrepreneurial Orientation (EO) \\
\hline Intercept & 2.595 \\
& $(0.000)$ \\
Market knowledge & 0.061 \\
& $(0.171)$ \\
Network knowledge & 0.009 \\
& $(0.742)$ \\
Cultural knowledge & 0.044 \\
& $(0.253)$ \\
Entrepreneurial knowledge & $0.803 * * *$ \\
& $(0.000)$ \\
$F$-value & 100908 \\
$p$-value & 0.000 \\
$R$-squared & 0.111 \\
$N$ & 353 \\
\hline &
\end{tabular}

\subsection{Scientific Discussion}

A review of the literature on entrepreneurial orientation and knowledge in the internationalization process of firms, as well as our own research, reveal the abundant exploration possibilities of this topic. Referring to the questions posed in the introduction of the article, it should be noted that both entrepreneurial orientation and knowledge are of key importance in the process of internationalization. Almost all research hypotheses on this topic were verified positively. This is also in accordance with the majority of prior research. Zehir, Can, and Koraboga [104] presented findings which empirically supported the positive correlation between entrepreneurial orientation and the internationalization of firms, stressing the importance of diversified strategies and innovative activities in this relationship. Gupta and Gupta [105] observed that entrepreneurial orientation has a strong initial impact on the firm's performance but this effect gradually decreases over time. The significance of entrepreneurial orientation in the internationalization process was also visible in the studies of Yoon, Kim, and Dedahanov [34] as well as the work by Etemad [19]. Zonta and Amal [106] indicated the importance of innovativeness among all components of entrepreneurial orientation, especially for born global firms. Matiusinaite and Sekliuckiene [107] observed that risk-taking and initiative are regarded as being among the most important determinants in finding international opportunities and increasing the volume of international activities. This study allowed us to transpose applications similar to those confirmed in tested hypotheses (H1, H1a, c) to Polish companies. Similar conclusions were presented by Sharma and Blomstermo [63] as well as Andersson and Evers [66] in the context of proactiveness as a key attribute of the internationalization of born global firms. However, our study of a sample of Polish firms did not confirm the importance of proactiveness for internationalization (H1b).

The final question from the introduction must also be emphasized. Although international orientation has a quite long tradition as a central concept in explanations of various aspects of the internationalization of firms, it has usually been analyzed solely. In this study, we introduced different types of knowledge and confirmed that firms with a higher level of entrepreneurial orientation use these types of knowledge more intensively at different stages of internationalization. In our study, we proved that both entrepreneurial orientation and knowledge are key determinants of the internationalization of firms (H1, H2, H3). Combining these two aspects, it is necessary to point out that the existing literature in this field is quite poor. However, the studies conducted so far affirm the importance and positive relationship between entrepreneurial orientation and knowledge in the internationalization process $[99,108]$. This was partially confirmed by our investigation (H4). Gupta and Niranjan [109] investigated the strategic alliances of small and medium-sized enterprises, and concluded that entrepreneurial orientation is positively correlated with the creation and acquisition 
of knowledge in key customer alliances, but has no significant connection with knowledge creation and acquisition in key supplier alliances. In turn, in our study, it should be noted that the use of knowledge differs depend on the stage of internationalization. The utilization of knowledge is therefore not identical at all stages of the internationalization process. The most important conclusion resulting from the comparison of prior research is that there is a strong need to continue studies in this field $[26,88]$.

\section{Conclusions}

\subsection{Summary of Findings}

Nowadays, entrepreneurial orientation is one of the more important issues discussed within research on internationalization. The main components of entrepreneurial orientation include risk-taking, innovativeness, and proactiveness, which are regarded as significant causative factors of effective internationalization. Including the aspect of knowledge in the deliberations on entrepreneurial orientation and internationalization seems to be naturally justified on the grounds of theoretical concepts; however, it is an area that has been neglected in empirical research. This article combined the issue of entrepreneurial orientation and knowledge using the example of Polish firms. On the basis of the conducted analysis, we found that entrepreneurial orientation is substantial in the use of knowledge in the internationalization process. Firms characterized by higher entrepreneurial orientation used individual types of knowledge much more intensely at various stages of internationalization. Network knowledge was more used by those firms both in the initial and mature internationalization phases. On the other hand, entrepreneurial knowledge was used intensely at the stage of mature internationalization. Market knowledge and sociocultural knowledge were by far more explored in the initial internationalization stage.

Therefore, based on the conducted statistical analysis, we can positively verify three assumed hypotheses (H1, H2, and H3). However, we can only partially accept the verified research hypothesis $\mathrm{H} 4$, as not all types of knowledge were explored to the same extent at different internationalization stages by firms characterized by higher entrepreneurial orientation (Table 7). Answering RQ1, it should be noted that the relation between entrepreneurial orientation and internationalization was positive. This means that entrepreneurial orientation positively influences internationalization, particularly the scope of internationalization. The higher the level of entrepreneurial orientation, the greater the number of foreign markets in which a firm operates. This was confirmed by H1. A similar answer applies to RQ2 and RQ3. Entrepreneurial knowledge plays a significant positive role in entrepreneurial orientation in the process of the internationalization of firms, as confirmed by $\mathrm{H} 2$. In accordance with $\mathrm{H} 3$, it should be noted that different types of knowledge significantly affect the intensification of the internationalization scale.

Table 7. Verification of assumed hypotheses and answers for research questions.

\begin{tabular}{|c|c|c|c|c|}
\hline Question & & Hypothesis and its Essence & Result & Method \\
\hline RQ1 & H1: & $\begin{array}{l}\text { Positive effect of EO (multidimensional construct) on } \\
\text { internationalization scope (as for unidimensional } \\
\text { constructs, only two out of three (H1a and H1c-namely, } \\
\text { innovativeness and risk-taking) were confirmed }\end{array}$ & Confirmed & $\begin{array}{l}\text { Multivariate } \\
\text { regression }\end{array}$ \\
\hline RQ2 & H2: & $\begin{array}{l}\text { Stimulating effect of knowledge utilization on EO in } \\
\text { international context }\end{array}$ & Confirmed & $\begin{array}{l}t \text {-test and } \\
\text { multivariate } \\
\text { regression }\end{array}$ \\
\hline RQ3 & H3: & $\begin{array}{l}\text { Positive effect of knowledge utilization on } \\
\text { internationalization scale }\end{array}$ & Confirmed & $\begin{array}{l}\text { Multivariate } \\
\text { regression }\end{array}$ \\
\hline RQ4 & H4: & $\begin{array}{l}\text { Impact of EO on the use of knowledge in various phases } \\
\text { of internationalization }\end{array}$ & $\begin{array}{l}\text { Partially } \\
\text { supported }\end{array}$ & $t$-test \\
\hline
\end{tabular}

\subsection{Contribution and Implications for Practice}

This article goes much further than existing research in the search for the mediating point between entrepreneurial orientation and internationalization. However, attention should be also paid 
to other factors which, by means of entrepreneurial orientation, influence the internationalization process (organizational culture, management, etc.). What is more, this study adopted an assumption concerning the types of knowledge, thus it is recommended to verify the research problem posed by adopting other taxonomies of knowledge. Therefore, it is recommended to carry out further research to eliminate the indicated limitations.

On the basis of our findings, we can make some important recommendations for business practice. One should primarily promote awareness among managers and executives about the significance of the entrepreneurial orientation of firms. What is more, the knowledge about particular components of entrepreneurial orientation should be developed and, through training and good practice, stimulate the human capital of the firm to engage in activities consistent with the entrepreneurial constructs: proactiveness, innovativeness, and risk-taking. It is also necessary to train managers in the field of building business networks and acquiring not only market knowledge but also experimental knowledge.

\subsection{Research Limitations}

Just like with any research, especially those empirical in nature, the analysis presented in this article has its research limitations. These are mainly conditioned by the method of the sample selection, used measurements, and analytical apparatus. Above all, the survey enforced the use of managerial perception, so measurable corporate data was not dealt. Only the perception of analyzed phenomena by managerial staff was included (which is natural to surveys). For the reason stated, it was not possible to absolutize the results. Thus, further in-depth research on this topic is still needed.

The paper has not only cognitive but also applicative character. However, it is not deprived of limitations. Firstly, it is a study conducted on a sample of Polish firms, and the research findings cannot be generalized. Moreover, it is a cross-sectional study, which makes it impossible to verify cause and effect relationships between the studied variables, which is possible only when conducting dynamic research. As mentioned before, we applied only a quasi-dynamic period, not a dynamic research approach.

\subsection{Suggestions for Future Research}

Future research may include international comparative analyses of the studied problem. The need for comparative research is widely discussed within the framework of international entrepreneurship. There is strong dissatisfaction with the research on emerging and developing markets. What is more, it is worth continuing research not only on the relationship between entrepreneurial orientation and knowledge in the internationalization process, but also on factors determining this relationship. The great benefit and added value of future research would be to investigate in detail the various components of entrepreneurial orientation, different taxonomies of knowledge, and various aspects of the internationalization process such as scope, scale, and speed. This multidimensional perspective requires the use of advanced research methods. The need for the implementation of quantitative and complex research methods in future research is evident. This topic has very large exploration potential. Therefore, it is strongly recommended to continue and deepen the research.

Author Contributions: The contribution of co-authors is equal and amounts to 33\% for each of them. The detailed contribution is as follows: conceptualization, methodology, supervision, and project administration-K.W.; writing of the literature review and introduction-A.G. and M.M.; conclusions-A.G., M.M., and K.W.

Funding: The article came into being within the OPUS 4 project entitled "Behaviours of Polish firms in the internationalization process in the perspective of international entrepreneurship", which was realized in the years 2013-2018 at the Faculty of Economics and International Relations of Cracow University of Economics. The project was financed by the funds from the National Science Centre $(\mathrm{NCN})$ granted on the base of the decision number DEC-2012/07/B/HS4/00701.

Acknowledgments: We would like to thank the three anonymous reviewers and Ondřej Dvouletý as the guest editor for their valuable comments which helped us to increase the quality of this article. 
Conflicts of Interest: The authors declare no conflict of interest.

\section{Appendix A}

Table A1. Measurement items for knowledge types acquisition and utilization.

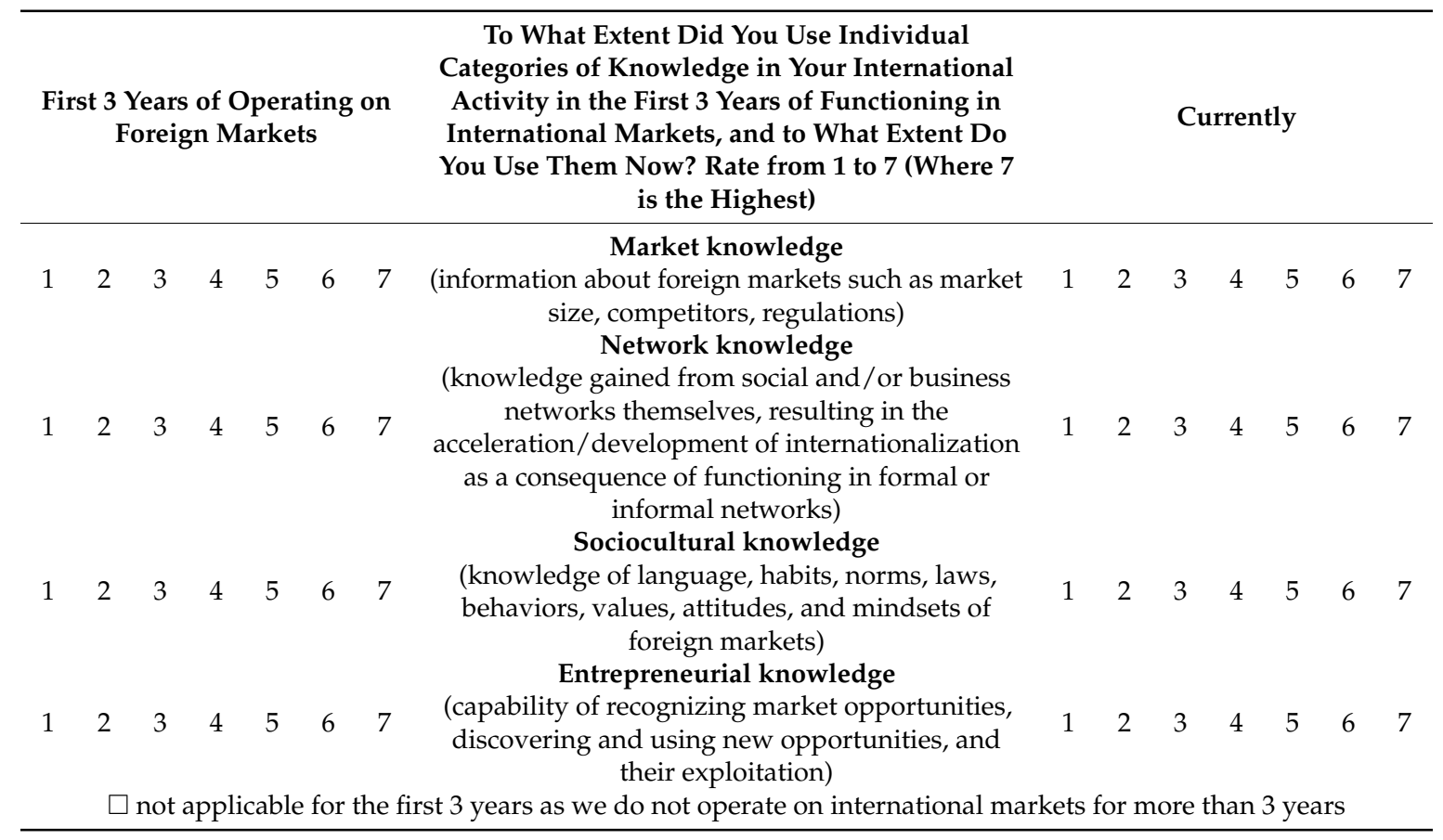

Source: own elaboration and compilation based on Mejri and Umemoto [24].

\section{References}

1. McMillan, J.; Woodruff, C. The Central Role of Entrepreneurs in Transition Economies. J. Econ. Perspect. 2002, 16, 153-170. [CrossRef]

2. Stam, E.; van Stel, A. Types of Entrepreneurship and Economic Growth. UNU-WIDER Res. Pap. 2009, 47, 1-16.

3. Ateljevic, J.; Trivić, J. Economic Development and Entrepreneurship in Transition Economies; Springer: Berlin, Germany, 2016.

4. Van Vuuren, J.; Alemayehu, B.Z. The role of entrepreneurship in transforming efficiency economies into innovation-based economies. S. Afr. J. Entrep. Small Bus. Manag. 2018, 10. [CrossRef]

5. Wach, K. Poland. In Youth Work and Entrepreneurial Learning. Country Reports; Andersen, T., Hougaard, K.F., Eds.; Publications Office of the European Union: Luxembourg, 2017; pp. 272-288.

6. Surdej, A.; Wach, K. Small and Medium-sized Enterprises in Poland. ERENET Prof. 2007, 2, 9-13. [CrossRef]

7. Ubrežiová, I.; Wach, K.; Horváthová, J. Entrepreneurship in small and medium-sized enterprises: Comparative study between Slovakia and Poland for the years 2001-2007. Agric. Econ. 2008, 54, 358-366. [CrossRef]

8. Dvouletý, O. What is the Relationship between Entrepreneurship and Unemployment in Visegrad Countries? Cent. Eur. Bus. Rev. 2017, 6, 42-53. [CrossRef]

9. Wach, K. Poland 2017. Inclusive Entrepreneurship Policies. Country Assessment Notes; OECD-European Commission: Paris, France; Brussels, Belgium, 2017.

10. Singer, S.; Herrington, M.; Menipaz, E. (Eds.) Global Entrepreneurship Monitor; Global Report 2017/2018; Global Entrepreneurship Research Association: Wellesley, MA, USA, 2018.

11. Oviatt, B.M.; McDougall, P.P. Towards a Theory of International New Ventures. J. Int. Bus. Stud. 1994, 25, 45-64. [CrossRef]

12. Oviatt, B.M.; McDougall, P.P. Defining international entrepreneurship and modeling the speed of internationalization. Entrep. Theory Pract. 2005, 29, 537-554. [CrossRef] 
13. Knight, G.A.; Cavusgil, S.T. The Born Global firm: A challenge to traditional internationalization theory. Adv. Int. Mark. 1996, 8, 11-26.

14. Autio, E.; Sapienza, H.J.; Almeida, J.G. Effects of Age at Entry, Knowledge Intensity, and Imitability on International Growth. Acad. Manag. J. 2000, 43, 909-924. [CrossRef]

15. Jones, M.V.; Coviello, N.E. Internationalisation: Conceptualising an entrepreneurial process of behaviour in time. J. Int. Bus. Stud. 2005, 36, 284-303. [CrossRef]

16. Dess, G.G.; Lumpkin, G.T. The Role of Entrepreneurial Orientation in Stimulating Corporate Entrepreneurship: Research Briefs. Acad. Manag. Exec. 2005, 19, 147-156.

17. Covin, J.G.; Slevin, D. Strategic Management of Small Firms in Hostile and Benign Environments. Strateg. Manag. J. 1989, 10, 75-87. [CrossRef]

18. Lumpkin, G.T.; Dess, G.G. Clarifying the Entrepreneurial Orientation Construct and Linking It to Performance. Acad. Manag. Rev. 1996, 21, 135-172. [CrossRef]

19. Etemad, H. Entrepreneurial orientation-performance relationship in the international context. J. Int. Entrep. 2015, 13, 1-6. [CrossRef]

20. Kropp, F.; Lindsay, N.J.; Shoham, A. Entrepreneurial orientation and international entrepreneurial business venture startup. Int. J. Entrep. Behav. Res. 2008, 14, 102-117. [CrossRef]

21. Wach, K. What Determines Entrepreneurial Orientation of Polish Internationalized Firms. J. Manag. Financ. Sci. 2017, 10, 43-65.

22. Rauch, A.; Wiklund, J.; Lumpkin, G.; Frese, M. Entrepreneurial Orientation and Business Performance: An Assessment of Past Research and Sugestions for the Future. Entrep. Theory Pract. 2009, 33, 761-787. [CrossRef]

23. Zucchella, A. Born globals versus gradually internationalizing firms: An analysis based on Italian case studies. In Proceedings of the European International Business Academy (EIBA) Annual 28th EIBA Conference, Athens, Greece, 8-10 December 2002.

24. Mejri, K.; Umemoto, K. Small- and medium-sized enterprise internationalization: Towards the knowledge-based model. J. Int. Entrep. 2010, 8, 156-167. [CrossRef]

25. Hutzschenreuter, T.; Kleindienst, I.; Guenther, C.; Hammes, M. Speed of Internationalization of New Business Units: The Impact of Direct and Indirect Learning. Manag. Int. Rev. 2016, 56, 849-878. [CrossRef]

26. Bingham, C.B.; Davis, J.P. Learning sequences: Their existence, effect, and evolution. Acad. Manag. J. 2012, 55, 611-641. [CrossRef]

27. Eriksson, K.; Johanson, J.; Majkgard, A.; Sharma, D.D. Experiential knowledge and cost in the internationalization process. J. Int. Bus. Stud. 1997, 28, 337-360. [CrossRef]

28. Åkerman, N. International opportunity realization in firm internationalization: Non-linear effects of market-specific knowledge and internationalization knowledge. J. Int. Entrep. 2015, 13, 242-259. [CrossRef]

29. Sjöholm, F. International transfer of knowledge: The role of international trade and geografic proximity. Rev. World Econ. 1996, 132, 97-115. [CrossRef]

30. Villar, C.; Alegre, J.; Pla-Barber, J. Exploring the role of knowledge management practices on exports: A dynamic capabiliteis view. Int. Bus. Rev. 2014, 23, 38-44. [CrossRef]

31. Geldres-Veiss, V.V.; Uribe-Bórques, T.C.; Coudounaris, N.D.; Monreal-Pérez, J. Innovation and experiential knowledge in firm exports: Applying the initial U-model. J. Bus. Res. 2016, 69, 5076-5081. [CrossRef]

32. Hsu, W.-T.; Chen, H.-L.; Cheng, C.-Y. Internationalization and firm performance of SMEs: The moderating effects of CEO attributes. J. World Bus. 2013, 48, 1-12. [CrossRef]

33. Tolstoy, D. The Proactive Initiation of SMEs' Foreign Business Relationships. Eur. Manag. Rev. 2018, 15, 1-15. [CrossRef]

34. Yoon, J.; Kim, K.K.; Dedahanov, A.T. The Role of International Entrepreneurial Orientation in Successful Internationalization from the Network Capability Perspective. Sustainability 2018, 10, 1709. [CrossRef]

35. Hanif, M.I.; Malik, F.; Hamid, A.B.A. The effect of knowledge management and entrepreneurial orientation on organization performance. J. Entrep. Educ. 2018, 21, 1-12.

36. Cui, L.; Fan, D.; Guo, F.; Fan, Y. Explicating the relationship of entrepreneurial orientation and firm performance: Underlying mechanisms in the context of an emerging market. Ind. Mark. Manag. 2018, 71, 27-40. [CrossRef]

37. Perényi, Á.; Losoncz, M. A Systematic Review of International Entrepreneurship Special Issue Articles. Sustainability 2018, 10, 3476. [CrossRef] 
38. Shane, S.; Venkataraman, S. The promise of entrepreneurship as a field of a research. Acad. Manag. Rev. 2000, 25, 217-226. [CrossRef]

39. Zahra, S.A. Governance, Ownership, and Corporate Entrepreneurship: The Moderating Impact of Industry Technical Opportunities. Acad. Manag. J. 1996, 39, 1713-1735.

40. Krueger, N.F.; Carsrud, A.L. Entrepreneurial intensions: Applying the theory of planned behavior. Entrep. Theory Pract. 1993, 5, 315-330.

41. Wickham, P.A. Strategic Entrepreneurship, 4th ed.; Prentice Hall: Harlow, UK, 2006.

42. Miller, D. The Correlates of Entrepreneurship in Three Types of Firms. Manag. Sci. 1983, 29, 770-791. [CrossRef]

43. Zelweger, T.; Sieger, P. Entrepreneurial orientation in long-lived family firms. Small Bus. Econ. 2012, 38, 67-84. [CrossRef]

44. Wiklund, J.; Shepherd, D. Entrepreneurial Orientation and Small Business Performance: A Configurational Approach. J. Bus. Ventur. 2005, 20, 71-91. [CrossRef]

45. Covin, J.G.; Miller, D. International Entrepreneurial Orientation: Conceptual Considerations, Research Themes, Measurement Issues, and Future Research Directions. Entrep. Theory Pract. 2014, 38, 11-44. [CrossRef]

46. Kollmann, T.; Christofor, J. International entrepreneurship in the network economy: Internationalization propensity and the role of entrepreneurial orientation. J. Int. Entrep. 2014, 12, 43-66. [CrossRef]

47. Gabrielsson, M.; Gabrielsson, P.; Dimitratos, P. International Entrepreneurial Culture and Growth of International New Ventures. Manag. Int. Rev. 2014, 54, 445-471. [CrossRef]

48. McDougall, P.P.; Oviatt, B.M. International Entrepreneurship: The Intersection of Two Research Paths. Acad. Manag. J. 2000, 43, 902-906.

49. Knight, G.A. Entrepreneurship and Strategy in the International SME. J. Int. Manag. 2001, 7, $155-171$. [CrossRef]

50. Wach, K. Entrepreneurial Orientation and Business Internationalisation Process: The Theoretical Foundations of International Entrepreneurship. Entrep. Bus. Econ. Rev. 2015, 3, 9-24. [CrossRef]

51. Knight, G.A. Cross-cultural reliability and validity of a scale to measure firm entrepreneurial orientation. J. Bus. Ventur. 1997, 12, 213-225. [CrossRef]

52. Florida, R. The Globalization of R\&D: Results of a Survey of Foreign-affiliated R\&D Laboratories in the USA. Res. Policy 1997, 23, 85-103.

53. Laranja, M.; Fontes, M. Creative adaptation: The role of new technology based firms in Portugal. Res. Policy 1998, 26, 1023-1036. [CrossRef]

54. Meyer-Krahmer, F.; Reger, G. New perspectives on the innovation strategies of multinational enterprises: Lessons for technology policy in Europe. Res. Policy 1999, 28, 751-776. [CrossRef]

55. Taggart, J.H. MNC subsidiary performance, risk, and corporate expectations. Int. Bus. Rev. 1999, 8, $233-255$. [CrossRef]

56. Knight, G.A. Entrepreneurship and Marketing Strategy: The SME under Globalisation. J. Int. Mark. 2000, 8, 12-32. [CrossRef]

57. Yiu, D.W.; Lau, C.; Bruton, G.D. International venturing by emerging economy firms: The effects of firm capabilities, home country networks, and corporate entrepreneurship. J. Int. Bus. Stud. 2007, 4, 519-540. [CrossRef]

58. Swoboda, B.; Olejnik, E. Linking Processes and Dynamic Capabilities of International SMEs: The Mediating Effect of International Entrepreneurial Orientation. J. Small Bus. Manag. 2016, 54, 139-161. [CrossRef]

59. Andersen, J.A. Critical Examination of the EO-Performance Relationship. Int. J. Entrep. Behav. Res. 2010, 16, 309-328. [CrossRef]

60. Zahra, S.; Garvis, D. International Corporate Entrepreneurship and Firm Performance: The Moderating Effect of International Environmental Hostility. J. Bus. Ventur. 2000, 15, 469-492. [CrossRef]

61. Emöke-Szidónia, F. International entrepreneurial orientation and performance of Romanian small and medium-sized firms: Empirical assessment of direct and environment moderated relations. Procedia Econ. Financ. 2015, 32, 186-193. [CrossRef]

62. Zahra, S.; Covin, J. Contextual Influence on the Corporate Entrepreneurship Performance Relationship: A Longitudinal Analysis. J. Bus. Ventur. 1995, 10, 43-58. [CrossRef] 
63. Sharma, D.D.; Blomstermo, A. The internationalization process of born globals: A network view. Int. Bus. Rev. 2003, 12, 739-753. [CrossRef]

64. Weerawardena, J.; Mort, G.S.; Liesch, P.W.; Knight, G. Conceptualizing accelerated internationalization in the born global firm: A dynamic capabilities perspective. J. World Bus. 2007, 42, 294-306. [CrossRef]

65. Andersson, S. International entrepreneurship, born globals and the theory of effectuation. J. Small Bus. Enterp. Dev. 2011, 18, 627-643. [CrossRef]

66. Andersson, S.; Evers, S. International opportunity recognition in international new ventures-A dynamic managerial capabilities perspective. J. Int. Enterp. 2015, 13, 260-276. [CrossRef]

67. Kowalik, I.; Danik, L.; Sikora, T. Entrepreneurial orientation elements in the Polish international new ventures. Balt. J. Manag. 2017, 12, 194-213. [CrossRef]

68. Wach, K. Orientacja przedsiębiorcza a wiedza w początkowym i dojrzałym etapie procesu internacjonalizacji przedsiębiorstw. Studia Ekonomiczne Zeszyty Naukowe Uniwersytetu Ekonomicznego w Katowicach 2017, 319, 268-282.

69. Johanson, J.; Vahlne, J.-E. The Internationalization Process of the Firms-A Model of Knowledge Development and Increasing Foreign Market Commitments. J. Int. Bus. Stud. 1977, 8, 23-32. [CrossRef]

70. Keen, C.; Wu, Y. An ambidextrous learning model for the internationalization of firms from emerging economies. J. Int. Entrep. 2011, 9, 316-339. [CrossRef]

71. Prashantham, S. Toward a Knowledge-Based Conceptualization of Internationalization. J. Int. Entrep. 2005, 3, 37-52. [CrossRef]

72. Forsgren, M. The concept of learning in the Uppsala internationalization process model: A critical review. Int. Bus. Rev. 2002, 11, 257-277. [CrossRef]

73. Widding, L. Building entrepreneurial knowledge reservoirs. J. Small Bus. Enter. Dev. 2005, 12, 595-612. [CrossRef]

74. De Clercq, D.; Arenius, P. The role of knowledge in business start-up activity. Int. Small Bus. J. 2006, 24, 339-358. [CrossRef]

75. Linan, F.; Chen, Y.W. Development and cross-cultural application of a specific instrument to measure entrepreneurial intentions. Entrep. Theory Pract. 2009, 33, 593-617. [CrossRef]

76. Gurel, E.; Altinay, L.; Daniele, R. Tourism students' entrepreneurial intentions. Ann. Tour. Res. 2010, 37, 646-669. [CrossRef]

77. Hohenthal, J.; Johanson, J.; Johanson, M. Network Knolwedge and business-Relationship value in the foreign market. Int. Bus. Rev. 2014, 23, 4-19. [CrossRef]

78. Yasir, M.; Majid, A.; Yasir, M. Entrepreneurial knowledge and start-up behavior in a turbulent environment. J. Manag. Dev. 2017, 36, 1149-1159. [CrossRef]

79. Casillas, J.C.; Moreno, A.M.; Acedo, F.J.; Gallego, M.A.; Ramos, E. An Integrative Model of the Role of Knowledge in the Internationalization Process. J. World Bus. 2009, 44, 311-322. [CrossRef]

80. Grant, R. Toward a knowledge based theory of the firm. Strateg. Manag. J. 1996, 17, 109-122. [CrossRef]

81. Petersen, B.; Pedersen, T.; Sharma, D.D. The role of knowledge in firms' internationalisation process: Where from and where to? In Learning in the Internationalisation Process of Firms; Blomstermo, A., Sharma, D.D., Eds.; Edward Elgar Publishing, Inc.: Northampton, MA, USA, 2003; pp. 36-55.

82. Johanson, J.; Vahlne, J.-E. Business relationship commitment and learning in the internationalization process. J. Int. Entrep. 2003, 1, 83-101. [CrossRef]

83. Johanson, J.; Vahlne, J.E. The Uppsala internationalization process model revisited: From liability of foreignness to liability of outsidership. J. Int. Bus. Stud. 2009, 40, 1411-1431. [CrossRef]

84. Xie, Y.; Amine, L. Social networks and the internationalization of Chinese entrepreneurs. Glob. Bus. Organ. Excell. 2009, 29, 61-78. [CrossRef]

85. Sommer, L.; Haug, M. Intention as a cognitive antecedent to international entrepreneurship: Understanding the moderating roles of knowledge and experience. Int. Entrep. Manag. J. 2011, 7, 111-142. [CrossRef]

86. Prashantham, S.; Berry, M.M.J. The small knowledge-intensive firm: A conceptual discussion of its characteristics and internationalisation. Int. J. Entrep. Innov. Manag. 2004, 4, 150-155. [CrossRef]

87. Brennan, L.; Garvey, D. The role of knowledge in internationalization. Res. Int. Bus. Financ. 2009, 23, 120-133. [CrossRef]

88. Hadley, R.D.; Wilson, H.I.M. The network model of internationalisation and experiential knowledge. Int. Bus. Rev. 2003, 12, 697-717. [CrossRef] 
89. Fletcher, M.; Harris, S. Knowledge acquisition for the internationalization of the smaller firm: Content and sources. Int. Bus. Rev. 2012, 21, 631-647. [CrossRef]

90. Acedo, F.J.; Jones, M. Speed of internationalization and entrepreneurial cognition: Insights and a comparison between international new ventures, exporters and domestic firms. J. World Bus. 2007, 42, 236-252. [CrossRef]

91. Freeman, S.; Edwards, R.; Schroder, B. How Smaller Born-Global Firms Use Networks and Alliances to Overcome Constraints to Rapid Internationalization. J. Int. Mark. 2006, 14, 33-63. [CrossRef]

92. Madsen, T.K.; Servais, P. The Internationalization of Born Globals: An Evolutionary Process? Int. Bus. Rev. 1997, 6, 561-583. [CrossRef]

93. Moen, $\varnothing$. The Born Globals: A new generation of small European exporters. Int. Mark. Rev. 2002, 19, $156-175$. [CrossRef]

94. Fernhaber, S.A.; McDougall-Covin, P.P.; Shepherd, D.A. International Entrepreneurship: Leveraging Internal and External Knowledge Sources. Strateg. Entrep. J. 2009, 3, 297-320. [CrossRef]

95. Cesinger, B.; Fink, M.; Madsen, T.; Kraus, S. Rapidly internationalizing ventures: How definitions can bridge the gap across contexts. Manag. Decis. 2012, 50, 1816-1842. [CrossRef]

96. Fletcher, D. International entrepreneurship and the small business. Entrep. Reg. Dev. 2004, 16, $289-305$. [CrossRef]

97. Wiklund, J.; Shepherd, D. Knowledge-based resources, entrepreneurial orientation, and the performance of small and medium sized businesses. Strateg. Manag. J. 2003, 24, 1307-1314. [CrossRef]

98. Li, Y.-H.; Huang, J.-W.; Tsai, M.-T. Entrepreneurial Orientation and firm Performance: The Role of Knowledge Creation Process. Ind. Mark. Manag. 2009, 38, 440-449. [CrossRef]

99. Omar, N.A.; Md Aris, H.; Nazri, M.A. The effect of entrepreneurial orientation, innovation capability and knowledge creation on firm performance: A perspective on small scale entrepreneurs. J. Pengurusan 2016, 48, 187-200.

100. Gupta, V.K.; Moesel, D.M. The impact of entrepreneurial orientation on knowledge management in strategic alliances: Evidence from high-technology SMEs. In Proceedings of the Annual USASBE Conference, Orlando, FL, USA, 18-21 January 2007.

101. Lyon, D.W.; Lumpkin, G.T.; Dess, G.G. Enhancing entrepreneurial orientation research: Operationalizing and measuring a key strategic decision making process. J. Manag. 2000, 26, 1055-1085. [CrossRef]

102. UNCTAD. World Investment Report 1995. Transnational Corporations and Competitiveness; United Nations Conference on Trade and Development: Geneva, Switzerland, 1995.

103. Wooldridge, M.J. Introductory Econometrics: A Modern Approach, 5th ed.; South-Western Cengage Learining: Mason, OH, USA, 2012.

104. Zehir, C.; Can, E.; Karaboga, T. Linking Entrepreneurial Orientation to Firm Performance: The Role of Differentiation Strategy and Innovation Performance. Procedia-Soc. Behav. Sci. 2015, 210, 358-367. [CrossRef]

105. Gupta, V.K.; Gupta, A. The concept of entrepreneurial orientation. Foundations and Trends in Entrepreneurship. Org. Manag. J. 2015, 11, 55-137.

106. Zonta, T.C.; Amal, M. Internationalization and innovation: The case of a born global from Brazil. Rev. Int. Bus. 2018, 13, 63-76. [CrossRef]

107. Matiusinaite, A.; Sekliuckiene, J. Factors determining early internationalization of entrepreneurial SMEs: Theoretical approach. Int. J. Bus. Econ. Sci. Appl. Res. 2015, 8, 21-32.

108. Wiklund, J.; Shepherd, D. Aspiring for, and Achieving Growth: The Moderating Role of Resources and Opportunities. J. Manag. Stud. 2003, 40, 1919-1941. [CrossRef]

109. Gupta, V.K.; Niranjan, S. Entrepreneurial orientation and performance effectiveness: An examination of the mediating role of knowledge acquisition and creation in customer alliances. In Proceedings of the DSI Annual Conference, Boston, MA, USA, 19-22 November 2011.

(C) 2018 by the authors. Licensee MDPI, Basel, Switzerland. This article is an open access article distributed under the terms and conditions of the Creative Commons Attribution (CC BY) license (http:/ / creativecommons.org/licenses/by/4.0/). 